Jurnal IImiah Iqra'

2541-2108 [Online] 1693-5705 [Print]

Tersedia online di: http://journal.iain-manado.ac.id/index.php/JlI

\title{
Meningkatkan Kemampuan Motorik Halus Anak Melalui Metode Pemberian Tugas Menganyam Kertas Dan Melipat Kertas
}

\author{
Trimurti Utiarahman \\ Raudhatul Athfal Al-Mujahidin Tomohon, Sulawesi Utara \\ triutiarahman@gmail.com
}

\begin{abstract}
Abstrak
Penelitian ini bertujuan mendeskripsikan penerapan metode pemberian tugas menganyam kertas dan melipat kertas (origami) yang dapat meningkatkan kemampuan motorik halus pada anak. Penelitian menggunakan rancangan penelitian tindakan kelas. Subjek penelitian ialah anak taman kanak-kanak kelompok B Raudatul Athfal Al-Mujahidin Tomohon, Sulawesi Utara yang berjumlah 16 orang. Pelaksanaan tindakan dilaksanakan dalam siklus berulang yang terdiri dari 4 tahap, yaitu perencanaan, pelaksanaan, observasi, dan refleksi. Jenis data yang digunakan dalam penelitian ini yaitu kualitatif dan kuantitatif. Data kualitatif dianalisis menggunakan teknik kualitatif melalui tiga tahap yaitu reduksi data, paparan data, dan penyimpulan atau verifikasi data. Sedangkan, data kuantitatif dianalisis secara deskriptif menggunakan tabel frekuensi dan persentasi. Hasil penelitian menunjukkan bahwa metode pemberian tugas menganyam kertas dan melipat kertas (origami) dapat meningkatkan kemampuan motorik halus anak. Melalui pemberian tugas menganyam kertas dan melipat kertas (origami) ini motivasi belajar anak meningkat sehingga sangat mudah dapat meningkatkan kemampuan motorik halus anak. Oleh karena itu, metode penugasan menganyam dan melipat kertas (origami) dapat dijadikan bahan dalam menyusun desain pembelajaran khususnya pada anak taman kanak-kanak kelompok B.
\end{abstract}

Kata Kunci: kemampuan motorik halus, anak, menganyam kertas, melipat kertas

\begin{abstract}
The aim of this research was to describe the application of the method of giving task with floating and folding paper (origami) which could increase the children's fine motor skills. This study was conducted by used a class action research design. This research subjects were the children of the kindergarten group B Raudatul Athfal AlMujahidin Tomohon, North Sulawesi, which amounts to 16 people. The implementation of the actions was carried out in a repetitive cycle which consisting
\end{abstract}


of 4 stages, namely planning, implementation, observation, and reflection. The type of data which used in this study were qualitative and quantitative. Qualitative data were analyzed by using the qualitative techniques through three stages, namely data reduction, data exposure, and inference or data verification. Whereas, quantitative data were analyzed descriptively by using the frequency tables and percentages. The results showed that the method of giving task with floating and folding paper (origami) could increase the children's fine motor skills. Through giving the task of floating and folding paper (origami), the children's learning motivation increased so it's very easy to increasing the children's fine motor skills. Therefore, the method of giving task with floating and folding paper (origami) can be used as material in preparing the design of learning, especially in kindergarten children in group $B$.

Keywords: fine motor skills, children, floating paper, folding paper

\section{Pendahuluan}

Anak Taman Kanak-Kanak (TK)/Raudahtul Athfal (RA) merupakan anak yang berada dalam proses perkembangan, baik perkembangan fisik, intelektual, sosial, emosional maupun bahasa. Setiap anak memiliki karakteristik tersendiri, sehingga perkembangan setiap anak berbeda-beda, baik dalam kualitas maupun tempo perkembangannya. Perkembangan anak bersifat progresif dan berkesinambungan. Dalam rangka pendidikan anak usia dini inilah kelembagaan Taman KanakKanak/Raudhatul Athfal diperlukan.

Taman Kanak-kanak merupakan salah satu bentuk pendidikan pada jalur pendidikan formal sebagai lembaga pendidikan prasekolah. Lembaga ini sangat strategis dan penting dalam menyediakan pendidikan bagi anak usia 4-6 tahun (prasekolah). Anak prasekolah ini sering disebut dengan istilah masa emas (the golden age) karena pada masa ini pertumbuhan dan perkembangan kecerdasan anak berkembang sangat pesat, baik pertumbuhan dan perkembangan fisik motorik, perkembangan intelektual, moral, sosial, emosional, dan bahasa. Oleh karena itu, pengembangan secara tepat yang dilakukan pada usia dini akan menjadi penentu bagi perkembangan individu selanjutnya. Tugas Taman Kanak-Kanak adalah mempersiapkan anak dan memperkenalkan berbagai pengetahuan, sikap atau perilaku, dan keterampilan agar anak dapat melanjutkan kegiatan belajar yang sesungguhnya pada jenjang pendidikan selanjutnya.

Tingkat pencapaian perkembangan menggambarkan pertumbuhan dan perkembangan yang diharapkan dicapai anak pada rentang usia tertentu. Perkembangan anak yang dicapai merupakan integrasi aspek pemahaman nilai-nilai agama dan moral fisik, kognitif, bahasa dan sosio-emosional. Seorang guru 
hendaknya memahami tugas-tugas perkembangan anak usia TK/RA, kebutuhan dan minat serta permasalahan yang sering dihadapi anak. Dalam proses belajar mengajar guru dapat memilih metode pembelajaran yang tepat sesuai dengan tugas dan karakteristik perkembangan anak.

Bredekamp \& Carol (1996: 3) menyatakan program pendidikan anak usia dini adalah suatu pusat program kelompok, sekolah, atau fasilitas lain yang melayani anak-anak usia lahir sampai 8 tahun (An early childhood program is any group program in a center, school, or other facility that serves chidren from birth through age 8). Kedudukan pendidikan anak usai dini juga diatur dalam Undang-Undang RI Nomor 20 tahun 2003 tentang Sistem Pendidikan Nasional pada pasal 1 ayat 14 bahwa pendidikan anak usia dini adalah suatu upaya pembinaan yang ditujukan kepada anak sejak lahir sampai dengan usia enam tahun yang dilakukan melalui pemberian rangsangan pendidikan untuk membantu pertumbuhan dan perkembangan jasmani dan rohani agar anak memiliki kesiapan dalam memasuki pendidikan lanjut.

Pendidikan sejak usia dini merupakan landasan sekaligus pijakan penting bagi pengembangan pendidikan selanjutnya bagi anak. Pada pendidikan anak usia dini akan diletakkan dasar-dasar pendidikan bagi anak, sehingga segenap potensi yang dimiliki anak dapat dikembangkan secara maksimal. Dengan demikian, untuk membantu pertumbuhan dan perkembangan jasmani dan rohani anak agar memiliki kesiapan dalam memasuki pendidikan lebih lanjut, maka sangat dibutuhkan peranan guru yang lebih baik.

Pendidikan di TK/RA sebagai salah satu bentuk pendidikan formal di dalamnya terjadi proses belajar mengajar yang melibatkan banyak faktor antara lain anak didik, bahan, materi, fasilitas ataupun lingkungan. Pendidikan yang diselenggarakan di TK/RA adalah bentuk usaha sadar dan terencana untuk mewujudkan suasana belajar dan proses pembelajaran agar anak didik secara aktif mengembangkan potensi dirinya untuk memiliki kekuatan spiritual keagamaan, pengendalian diri, kepribadian, kecerdasan, akhlak mulia, serta keterampilan yang diperlukan untuk menjalani kehidupan dalam masyarakat, bangsa, dan negara.

Sesuai dengan standar kompetensi pendidikan anak-anak usia dini yang tertulis dalam Undang-undang RI Nomor 20 tahun 2003 tentang Sistem Pendidikan Nasional yaitu pengembangan fisik dan motorik anak pada usia dini bertujuan untuk memperkenalkan dan melatih gerakan kasar dan halus, meningkatkan mengelola, 
mengontrol gerakan tubuh dan koordinasi, serta meningkatkan keterampilan tubuh dan cara hidup sehat dengan demikian akan menunjang pertumbuhan jasmani yang kuat, sehat dan terampil (Departemen Pendidikan Nasional, 2003).

Kenyataan yang ditemukan dalam proses belajar mengajar kemampuan motorik halus anak belum berkembang dengan baik. Oleh karena itu, agar motorik halus anak meningkat, perlu pemilihan metode penugasan yang dapat mengaktivasi pengembangan motorik halus anak. Salah satu metode yang dipandang efektif ialah pemberian tugas menganyam kertas dan melipat kertas. Dalam metode penugasan ini dibutuhkan ketekunan dan kesabaran. Survai pendahuluan menunjukkan bahwa masih banyak anak yang belum mampu melakukan dengan baik kegiatan menganyam kertas dan melipat kertas (origami) ini. Dari 16 anak, yang mampu mengerjakan tugas menganyam kertas hanya 4 orang anak dan melipat kertas 5 orang anak, dan itu pun masih dibantu oleh guru.

Berdasarkan uraian di atas, perlu dikaji apakah penerapan metode pemberian tugas menganyam kertas dan melipat kertas (origami) dapat meningkatkan kemampuan motorik halus pada anak. Oleh karena itu, artikel ini bertujuan mendeskripsikan penerapan metode pemberian tugas menganyam kertas dan melipat kertas yang dapat meningkatkan kemampuan motorik halus pada anak di TK/RA.

\section{Kajian Teori}

\section{Metode Pemberian Tugas}

Metode pemberian tugas adalah metode penyajian bahan dimana guru memberikan tugas tertentu agar siswa melakukan kegiatan belajar. Tugas biasanya bisa dilaksanakan di rumah, di sekolah, di perpustakaan, dan di tempat lainnya. Tugas yang diberikan tersebut bertujuan merangsang anak untuk aktif belajar, baik secara individual maupun secara kelompok. Karena itu, tugas dapat diberikan secara individual, atau dapat pula secara kelompok (Djamarah \& Zain, 2010, pp. 96-97). Dalam konteks pendidikan anak usai dini, Montolalu (2005, p. 86) mengemukakan metode pemberian tugas adalah metode yang secara sengaja diadakan dengan memberian tugas atau pekerjaan kepada anak TK untuk diselasaikan dengan baik. Tugas atau pekerjaan itu diberikan untuk memberikan kesempatan kepada anak untuk melaksanakan tugas berdasarkan petunjuk langsung yang telah disiapkan 
oleh guru sehingga anak dapat mengalami secara nyata dan melaksanakan secara awal sampai akhir secara tuntas.

Dengan kata lain, dapat dikemukakan bahwa metode pemberian tugas adalah suatu cara mengajar yang digunakan untuk membimbing anak didik memecahkan persoalan dengan cara memberikan tugas yang dikerjakan di dalam proses belajar mengajar di kelas. Tugas tersebut harus diselesaikan dan dikuasai anak didik dalam jangka waktu tertentu, kemudian dipertanggungjawabkan kepada guru yang bersangkutan.

Dalam pendidikan anak di TK/RA, penggunaan metode pemberian tugas ini setidaknya memberikan manfaat antara lain:

1. Untuk memberikan pengalaman belajar yang dapat meningkatkan cara belajar yang lebih baik dan memantapkan penguasaan perolehan hasil belajar.

2. Bila dirancang secara proportional dapat meningkatkan bagaimana cara belajar yang benar.

3. Apabila diberikan secara teratur, berkala akan menanamkan sikap belajar yang positif yang pada gilirannya dapat memotivasi anak untuk belajar sendiri, berlatih sendiri dan mempelajari kembali sendiri.

4. Apabila dirancang secara tepat dan seksama akan menghasilkan prestasi belajar secara optimal.

5. Bila menggunakan bahan yang bervariasi sesuai dengan kebutuhan dan minat, maka memberikan arti yang besar bagi anak TK dalam konteks dapat membangkitkan minat anak terhadap tugas yang akan diberikan berikutnya.

Metode pemberian tugas pada anak usia 4-6 tahun ini sangat bermanfaat terutama pada perkembangan motorik halus. Oleh karena itu, guru harus secara kreatif menggunakan metode pemberian tugas ini untuk dapat meningkatkan motorik halus pada anak. Salah satu jenis metode pemberian tugas yang dipandang efektif meningkatkan motorik halus pada anak adalah pemberian tugas menganyam kertas dan melipat kertas (origami). Menganyam kertas adalah suatu kegiatan keterampilan yang bertujuan untuk menghasilkan aneka benda/barang pakai dan benda seni, yang dilakukan dengan cara saling menyusupkan atau menumpang tindihkan bagian-bagian pita anyaman secara bergantian. Menganyam adalah 
kegiatan menjalinkan pita atau iratan yang disusun menurut arah dan motif tertentu.

Untuk anak usia dini, kegiatan menganyam tidak dilakukan dengan teknik yang kompleks, namun masih dalam tahap tehnik dasar menganyam sederhana. Kemampuan menganyam dapat mengasah keterampilan motorik halus anak karena menggunakan tangan dan jari-jari demikian juga dengan koordinasi mata. Selain keterampilan motorik halus yang dikembangkan, menganyam juga dapat digunakan sebagai alat untuk melatih logika anak, belajar matematika dan melatih konsentrasi.

Melipat kertas (origami) adalah suatu teknik berkarya seni/kerajinan tangan yang umumnya dibuat dari bahan kertas, dengan tujuan untuk menghasilkan aneka bentuk mainan, hiasan, benda fungsional, alat peraga, dan kreasi lainnya (Sumanto, 2006, p. 97). Kegiatan melipat kertas sangat terkenal di negara jepang karena perkembangan kreativitasnya sangat cepat (Pamadhi \& Sukardi, 2008, p. 76). Seni melipat kertas ini di Jepang dikenal dengan istilah origami. Kata origami terdiri dari dua kata yaitu oru dan kami. Oru berarti melipat dan kami berarti kertas.

Melipat merupakan kegiatan keterampilan tangan untuk menciptakan bentuk-bentuk tertentu tanpa menggunakan bahan perekat (lem). Kegiatan ini membutuhkan keterampilan koordinasi mata dan tangan, ketelitian, kerapian dan kreativitas. Apabila kegiatan ini sesuai dengan minat anak akan memberikan kegembiraan dan keasyikan serta kepuasan bagi anak.

Tujuan dari kegiatan melipat kertas (origami), yaitu (a) melatih konsentrasi dan ingatan anak, (b) melatih pengamatan, (c) mengembangkan ekspresi melalui media lukis, (d) mengembangkan fantasi, imajinasi, dan kreasi, (e) melatih otot-otot tangan/jari, koordinasi otot, mata, dan keterampilan tangan, (f) memupuk perasaan estetika, dan (g) memupuk ketelitian, kesabaran dan kerapian (Setiani, 2007, p. 319)..

\section{Metode}

Penelitian ini dilakukan dengan menggunakan rancangan penelitian tindakan kelas yang terdiri dari 4 tahap, yaitu perencanaan, pelaksanaan, observasi, refleksi. Jenis data yang digunakan dalam penelitian ini yaitu data kualitatif terkait peningkatan interaksi sosial anak yang diperoleh dari hasil pengamatan berdasarkan lembar observasi siswa serta aktivitas guru (peneliti). Data kuantitaf yaitu skor penilaian hasil pengamatan. 
Teknik analisa data yang digunakan yaitu teknik analisis kualitatif. Analisa data kualitatif dilakukan selama dan sesudah penelitian dilakukan di kelas melalui 3 tahap yaitu reduksi data, paparan data, dan penyimpulan atau verifikasi data. Data kuantitatif yang merupakan hasil kegiatan belajar anak yang dianalisis secara deskriptif dengan menggunakan pengelompokkan berdasarkan teknik kategori standar yaitu BM (Belum Muncul); MM (Mulai Muncul); BSH (Berkembang Sesuai Harapan); dan BSB (Berkembang Sangat Baik).

Data yang terkumpul diidentifikasi dan diklasifikasi berdasarkan tolok ukur (parameter) yang diteliti untuk kemudian diolah dan dianalisis dengan menggunakan tabel frekuensi dan persentasi dengan rumus (Sudjiono, 1991:40) sebagai berikut:

$$
P=f / n \times 100 \%
$$

Keterangan :

$\begin{array}{lll}\mathrm{P} & : & \text { Hasil yang dicapai } \\ \mathrm{f} & : & \text { Jumlah jawaban } \\ \mathrm{n} & : & \text { Jumlah sampel } \\ 100 & : & \text { Angka tetap }\end{array}$

Prosedur penelitian tindakan yang dilakukan yaitu meliputi;

\section{Pra Tindakan}

Dalam kegiatan ini peneliti melakukan observasi serta menganalisis letakletak penyebab dan juga faktor yang menjadikan kurangnya kemampuan motorik halus anak, melakukan pertemuan dan memastikan teman sejawat yang akan mendampingi peneliti.

\section{Pelaksanaan Tindakan}

Pelaksanaan tindakan dalam penelitian ini dilakukan secara bersiklus yang terdiri dari:

\section{Perencanaan}

Mempersiapkan rencana kegiatan harian terkait kegiatan yang akan dilaksanakan yaitu tentang peningkatan kegiatan kemampuan motorik halus anak, menyiapkan lembar observasi aktifitas anak didik. 


\section{Pelaksanaan tindakan}

Pada tahap ini guru (peneliti) menggunakan metode demontrasi dalam kegiatan belajar di kelas. Tapi jika dijumpai hal-hal di luar kemauan dan kemampuan bersama, maka metode ini dapat disesuaikan dengan situasi dan kondisi yang terjadi di lapangan. Pelaksanaan tindakan tersebut meliputi mengabsen anak, memberikan apersepsi, menjelaskan tentang kegiatan yang akan dilaksanakan, guru menjelaskan cara-cara mengerjakan tugas yang diberikan pada anak, guru meminta anak untuk mengerjaka tugas yang diberikan.

\section{Observasi}

Observasi dilakukan pada saat penelitian atau dalam proses kegiatan belajar anak. Kegiatan observasi dibantu oleh teman sejawat untuk mengamati semua aktivitas peneliti dan aktivitas anak dalam proses kegiatan. Hasil observasi dicatat dalam lembaran observasi aktivitas guru dan anak yang telah disediakan. Hasil pengamatan ini berupa data observasi untuk direfleksi sehingga pengamatan yang dilakukan dapat mendeskripsikan keadaan sesungguhnya mengenai peningkatan kemampuan motorik halus anak melalui metode pemberian tugas.

\section{Refleksi}

Kegiatan yang dilakukan pada tahap ini adalah menganalisis data yang diperoleh pada tahap observasi. Berdasarkan hasil analisis data dilakukan refleksi guna melihat kekurangan dan kelebihan yang terjadi saat pembelajaran diterapkan. Kekurangan dan kelebihan ini dijadikan acuan untuk merencanakan siklus berikutnya..

\section{Hasil}

\section{Deskripsi Hasil}

Dari data awal diketahui bahwa penggunaan metode mengajar dalam proses kegiatan belajar mengajar di RA Al-Mujahidin Tomohon kelompok B selama ini kurang bervariasi. Guru kurang menggunakan media dan strategi yang menarik minat anak. Metode ceramah yang digunakan kurang dikemas dengan baik, anakanak duduk mendengarkan sehingga mengakibatkan rendahnya minat dan perhatian anak yang berdampak pada hasil belajar yang kurang maksimal. Dalam konteks pembelajaran di TK/RA, guru merupakan sentra kegiatan dan memegang 
peranan penting di dalam memilih metode serta media yang tepat dalam proses pembelajaran.

1. Pra Tindakan

Berdasarkan data yang telah dikumpulkan sebelum tindakan yang disajikan pada tabel sebagai berikut:

Tabel 1. Rekapitulasi Hasil Pengamatan Pra Tindakan

\begin{tabular}{|c|c|c|c|c|c|c|c|}
\hline \multirow{3}{*}{ No. } & \multirow{3}{*}{ Kategori } & \multicolumn{4}{|c|}{ Aspek yang diamati } & \multirow{3}{*}{$\mathrm{Jml}$} & \multirow{3}{*}{$\%$} \\
\hline & & \multicolumn{2}{|c|}{$\begin{array}{l}\text { Anak yang } \\
\text { menganyam } \\
\text { kertas }\end{array}$} & \multicolumn{2}{|c|}{$\begin{array}{l}\text { Anak yang } \\
\text { melipat kertas } \\
\text { (origami) }\end{array}$} & & \\
\hline & & $\mathrm{F}$ & $\%$ & $\mathrm{~F}$ & $\%$ & & \\
\hline 1. & BSB & 1 & 6,25 & 1 & 6,25 & 2 & 6,25 \\
\hline 2. & $\mathrm{BSH}$ & 1 & 6,25 & 1 & 6,25 & 2 & 6,25 \\
\hline 3. & $M M$ & 2 & 12,50 & 3 & 18,75 & 5 & 15,63 \\
\hline 4. & BM & 12 & 75 & 11 & 68,75 & 23 & 71,87 \\
\hline & Jumlah & 16 & 100 & 16 & 100 & 32 & 100 \\
\hline
\end{tabular}

Berdasarkan data Tabel 1, pada aspek anak yang menganyam kertas terdapat 1 orang anak $(6,25 \%)$ yang masuk kategori berkembang sangat baik, 1 orang anak $(6,25 \%)$ yang masuk kategori berkembang sesuai harapan, 2 orang anak (12,50\%) yang masuk kategori mulai muncul dan 12 orang anak (75,00\%) yang masuk kategori belum muncul.

Pada aspek anak yang melipat kertas (origami) terdapat 1 orang anak $(6,25 \%)$ yang masuk kategori berkembang sangat baik, 1 orang anak $(6,25 \%)$ yang masuk kategori berkembang sesuai harapan, 3 orang anak (18,75\%) yang masuk kategori mulai muncul dan 11 orang anak $(68,75 \%)$ yang masuk kategori belum muncul.

Setelah dijumlahkan kedua aspek yang diamati diketahui dari 16 anak yang menjadi subjek penelitian terdapat 2 orang anak (6,25\%) yang masuk kategori berkembang sangat baik, 2 orang anak $(6,25 \%)$ yang masuk kategori berkembang sesuai harapan, 5 orang anak (15,63\%) yang masuk kategori mulai muncul dan 23 
orang anak (64,58\%) yang masuk kategori belum muncul. Sehingga dari hasil penelitian sementara atau pra tindakan menunjukkan bahwa terdapat permasalahan anak dalam menganyam kertas dan melipat kertas (origami), maka peneliti melaksanakan penelitian tindakan kelas dengan harapan dapat meningkatkan kemampuan motorik halus anak melalui metode pemberian tugas.

Kemungkinan hal ini disebabkan karena anak belum bisa beradaptasi dengan teman-temannya yang lain karena situasi sekolah yang baru, belum fokus dengan apa yang disampaikan oleh guru dan belum terbiasa dengan melakukan kegiatan yang berhubungan dengan fisik motorik halusnya seperti menganyam kertas dan melipat kertas (origami). Disamping itu kurangnya fasilitas atau media yang bisa membantu kemampuan anak, juga kebiasaan anak yang cenderung pasif. Kemungkinan penyebab selanjutnya rendahnya kemampuan anak dalam mengembangkan kemampuan motorik halus anak pada pra tindakan bisa bersumber dari lingkungan bermain dan juga situasi dan suasana belajar yang kurang menyenangkan. Kemungkinan juga pembelajaran yang sangat menoton, banyak aktivitas yang didominasi oleh guru atau pembelajaran yang berpusat pada guru. Hal-hal itu yang mendorong peneliti untuk melakukan perbaikan pembelajaran untuk melakukan tindakan siklus 1 dengan menggunakan metode pemberian tugas terbukti dapat dapat meningkatkan kemampuan motorik halus anak.

2. Tindakan Siklus I

Tindakan siklus I ini dilakukan dengan 3 kali pertemuan di kelas. Dalam penyajian materi, peneliti bertindak sebagai pengajar yang didampingi oleh teman sejawat yang bertindak sebagai pengamat. Adapun hasil pengamatan pada tindakan siklus I dapat dilihat pada Tabel 2 berikut ini.

Tabel 2. Rekapitulasi Hasil Pengamatan Tindakan Siklus I

\begin{tabular}{|c|c|c|c|c|c|c|c|}
\hline \multirow{3}{*}{ No. } & \multirow{3}{*}{ Kategori } & \multicolumn{4}{|c|}{ Aspek yang diamati } & \multirow{3}{*}{ Jumlah } & \multirow{3}{*}{$\%$} \\
\hline & & \multicolumn{2}{|c|}{$\begin{array}{l}\text { Anak yang } \\
\text { menganyam } \\
\text { kertas }\end{array}$} & \multicolumn{2}{|c|}{$\begin{array}{l}\text { Anak yang } \\
\text { melipat kertas } \\
\text { (origami) }\end{array}$} & & \\
\hline & & $\mathrm{F}$ & $\%$ & $\mathrm{~F}$ & $\%$ & & \\
\hline 1. & BSB & 3 & 18,75 & 5 & 31,25 & 8 & 25,00 \\
\hline
\end{tabular}




\begin{tabular}{|c|c|c|c|c|c|c|c|}
\hline 2. & $\mathrm{BSH}$ & 4 & 25 & 3 & 18,75 & 7 & 21,87 \\
\hline 3. & MM & 4 & 25 & 5 & 31,25 & 9 & 28,13 \\
\hline 4. & BM & 5 & 31,25 & 3 & 18,75 & 8 & 25,00 \\
\hline & umlah & 16 & 100 & 16 & 100 & 32 & 100 \\
\hline
\end{tabular}

Berdasarkan Tabel 2 di atas, pada aspek anak yang menganyam kertas terdapat 3 orang anak (18,75\%) yang masuk kategori berkembang sangat baik, 4 orang anak (25,00\%) yang masuk kategori berkembang sesuai harapan, 4 orang anak (25\%) yang masuk kategori mulai muncul dan 5 orang anak (31,25\%) yang masuk kategori belum muncul.

Pada aspek anak yang melipat kertas (origami) terdapat 5 orang anak (31,25\%) yang masuk kategori berkembang sangat baik, 3 orang anak (18,75\%) yang masuk kategori berkembang sesuai harapan, 5 orang anak (31,25\%) yang masuk kategori mulai muncul dan 3 orang anak (18,25\%) yang masuk kategori belum muncul.

Setelah dijumlahkan kedua aspek yang diamati diketahui dari 16 anak yang menjadi subjek penelitian terdapat 8 orang anak (25,00\%) yang masuk kategori berkembang sangat baik, 7 orang anak (21,87\%) yang masuk kategori berkembang sesuai harapan, 9 orang anak $(28,13 \%)$ yang masuk kategori mulai muncul dan 8 orang anak (25,00\%) yang masuk kategori belum muncul.

Pada siklus I yang telah direncanakan dengan dua kali tindakan dengan menggunakan metode pemberian tugas pada tema sekolahku. Sebelum penelitian terlebih dahulu peneliti berdiskusi dengan teman sejawat tentang rencana penelitian meminta kepadanya untuk membantu menjadi pengamat. Selanjutnya kami bersama-sama merancang pembelajaran dan persiapan yang harus dilaksanakan juga menyiapkan alat-alat sebagai media yang digunakan dalam kegiatan pembelajaran dalam kegiatan pembelajaran dalam tindakan siklus I.

Selama proses pembelajaran dimulai dari kegiatan awal, kegiatan inti dan penutup dengan 2 aspek yang akan diamati, yaitu menganyam kertas dan melipat kertas (origami). Fokus penelitian tindakan ini adalah penggunaan metode pemberian tugas untuk meningkatkan kemampuan motorik halus anak. Dengan menggunakan metode pemberian tugas yang digunakan dalam pembelajaran 
tentang tema sekolah yang diharapkan anak bisa menunjukkan kemampuan motorik halus berkembang sangat baik.

Hasil penelitian pada tindakan siklus I secara umum sudah menunjukkan peningkatan jika dibandingkan dengan pra tindakan. Dapat dibahas pada siklus I ini sudah menunjukkan peningkatan meskipun belum maksimal. Peningkatan dari beberapa kemampuan yang diamati seperti kemampuan menganyam kertas dan melipat kertas (origami), rata-rata sudah mengalami peningkatan.

Adapun faktor yang menyababkan adanya peningkatan kemampuan motorik halus anak tersebut tersebut dengan menggunakan metode pemberian tugas, dapat menarik minat dan perhatian anak. Dengan peningkatan minat dan perhatian tersebut diasumsikan menjadi pendorong meningkatnya kemampuan motorik halus anak. Di sisi lain dapat pula dianalisa masih ada beberapa anak yang belum menunjukkan hasil yang maksimal atau belum meningkat kemampuannya. Hal ini masih perlu dianalisa lagi apakah karena anak ini belum termotivasi atau media yang digunakan belum menarik minatnya.

Kemungkinan bisa pula disebabkan karena ada guru lain yang ikut dalam kegiatan belajar anak sehingga sangat mempengaruhi aktivitas anak yang masih malu-malu atau kurang memiliki keberanian. Kemungkinan lain bersumber dari lingkungan rumahnya yang tidak biasa diajak bermain belajar oleh teman atau anggota keluarganya. Maka peneliti berusaha untuk lebih meningkatkan media yang lebih banyak bervariasi. Di samping itu guru akan lebih memberi motovasi, dorongan serta semangat agar anak dapat meningkatkan kemampuannya dalam motorik halusnya. Untuk itu apa yang telah diperbaiki pada siklus kedua dapat dianalisa.

\section{Tindakan Siklus II}

Tindakan siklus II ini juga dilakukan dengan tiga kali pertemuan di kelas. Dalam penyajian materi, peneliti bertindak sebagai pengajar yang didampingi oleh teman sejawat yang bertindak sebagai pengamat. Adapun hasil pengamatan pada tindakan siklus II dapat dilihat pada Tabel 3 berikut ini. 
Tabel 3. Rekapitukasi Hasil Pengamatan Tindakan Siklus II

\begin{tabular}{|c|c|c|c|c|c|c|c|}
\hline \multirow{3}{*}{ No. } & \multirow{3}{*}{ Kategori } & \multicolumn{4}{|c|}{ Aspek yang diamati } & \multirow{3}{*}{ Jumlah } & \multirow{3}{*}{$\%$} \\
\hline & & \multicolumn{2}{|c|}{$\begin{array}{l}\text { Anak yang } \\
\text { menganyam } \\
\text { kertas }\end{array}$} & \multicolumn{2}{|c|}{$\begin{array}{l}\text { Anak yang } \\
\text { melipat kertas } \\
\text { (origami) }\end{array}$} & & \\
\hline & & $\mathrm{F}$ & $\%$ & $\mathrm{~F}$ & $\%$ & & \\
\hline 1. & BSB & 11 & 68,75 & 12 & 75 & 23 & 71,88 \\
\hline 2. & $\mathrm{BSH}$ & 2 & 12,50 & 2 & 12,50 & 4 & 12,50 \\
\hline 3. & $M M$ & 2 & 12,50 & 1 & 6,25 & 3 & 9,37 \\
\hline 4. & BM & 1 & 6,25 & 1 & 6,25 & 2 & 6,25 \\
\hline & Jumlah & 16 & 100 & 16 & 100 & 32 & 100 \\
\hline
\end{tabular}

Berdasarkan data pada Tabel 3 di atas, pada aspek anak yang menganyam kertas terdapat 11 orang anak (68,75\%) yang masuk kategori berkembang sangat baik, 2 orang anak (12,50\%) yang masuk kategori berkembang sesuai harapan, 2 orang anak (12,50\%) yang masuk kategori mulai muncul dan 1 orang anak $(6,25 \%)$ yang masuk kategori belum muncul.

Pada aspek anak yang melipat kertas (origami) terdapat 12 orang anak (75.00\%) yang masuk kategori berkembang sangat baik, 2 orang anak (12,50\%) yang masuk kategori berkembang sesuai harapan, 1 orang anak $(6,25 \%)$ yang masuk kategori mulai muncul dan 1 orang anak $(6,25 \%)$ yang masuk kategori belum muncul.

Setelah dijumlahkan kedua aspek yang diamati diketahui dari 16 anak yang menjadi subjek penelitian terdapat 23 orang anak (71,88\%) yang masuk kategori berkembang sangat baik, 4 orang anak (12,50\%) yang masuk kategori berkembang sesuai harapan, 3 orang anak (9,37\%) yang masuk kategori mulai muncul dan 2 orang anak (6,25\%) yang masuk kategori belum muncul.

Pada siklus II dengan dua kali tindakan menunjukkan yang sangat signifikan jika dibandingkan dengan siklus I atau pratindakan. Walaupun masih ada anak yang belum berhasil yaitu 1 anak dalam menganyam kertas dan 1 anak belum dapat 
melipat kertas (origami). Jika dirata-rata ada sekitar 6,25\% yang belum berhasil dari kemampuan yang diamati.

Dapat dikemukakan anak yang belum berhasil tersebut memang anak yang kurang yang memiliki rasa ingin tahu tentang sesuatu tugas atau permainan yang diberikan guru. Hal ini bukan berarti gagal, namun tetap ada peningkatan kemampuannya, tetapi belum maksimal. Oleh karena itu, peneliti dengan teman sejawat memutuskan untuk tidak melanjutkan siklus 3, karena anak yang belum berhasil presentasinya kecil. Sehingga penelitian tindakan kelas ini dikatakan berhasil dengan baik karena telah dapat memperbaiki proses pembelajaran yang berdampak dengan meningkatnya kreativitas anak pada beberapa kemampuan yang telah diamati. Oleh karena itu, pembelajaran dengan menggunakan metode pemberian tugas dapat meningkatkan motorik halus anak dalam kegiatan menganyam kertas dan melipat kertas (origami).

\section{Pembahasan}

Hasil penelitian pada Siklus I dan Siklus II menunjukkan bahwa ada peningkatan keterampilan motorik halus pada anak Kelompok B RA Al-Mujahidin Tomohon. Peningkatan keterampilan motorik halus anak terjadi pada setiap pertemuan. Hal tersebut dapat dilihat dari peningkatan persentase keterampilan motorik halus anak pada pratindakan yang mengalami peningkatan pada Siklus I dan Siklus II.

Hasil pengamatan menunjukkan bahwa anak Kelompok B dalam mengikuti kegiatan menganyam kertas dan melipat kertas (origami) sangat senang karena anak dapat belajar membuat mainan sendiri. Kegiatan origami khususnya juga dapat melatih konsentrasi dan ingatan anak karena pada kegiatan origami anak TK Kelompok B masih meniru sesuai perintah guru. Melalui kegiatan menganyam kertas dan melipat kertas (origami) dapat melatih kesabaran anak, di mana dua kegiatan ini memang cukup rumit dilakukan, sehingga untuk mencapai hasil yang sesuai bentuk yang diinginkan membutuhkan kesabaran.

Kegiatan menganyam kertas dan melipat kertas (origami) dapat melatih anak kelompok B untuk teliti artinya apakah lipatannya sudah lurus atau belum. Melatih kerapian, melipat kertas dengan hasil yang rapi akan terlihat indah bentuk lipatannya. Konsep sejalan dengan pendapat Sumanto (Sumanto, 2006) yang menyatakan bahwa tujuan kegiatan melipat kertas adalah untuk melatih daya ingat, 
pengamatan, keterampilan tangan, mengembangkan daya fantasi, kreasi, ketelitian, kerapian, dan perasaan keindahan.

Temuan penelitian ini membuktikan bahwa keterampilan motorik halus anak meningkat melalui kegiatan menganyam kertas dan melipat kertas (origami). Hal ini sejalan dengan temuan Purnamasari, dkk. (2014) yang menyatakan manfaat origami yaitu melatih motorik halus anak sekaligus sarana bermain yang aman, murah, dan kaya manfaat.

Hasil penelitian ini juga mengkonfirmasi aspek mendasar teori belajar behavioristik bahwa belajar merupakan perubahan kemampuan anak dalam bertingkah laku dengan adanya interaksi rangsangan dan respon. Relevansinya dengan hasil penelitian ini yaitu bahwa stimulus melalui kegiatan pemberian tugas menganyam kertas dan melipat kertas (origami) dapat menghasilkan respons berupa keterampilan motorik halus anak Kelompok B RA Al-Mujahidin Tomohon yang mengalami peingkatan. Dengan kata lain, motorik halus anak meningkat karena diberi stimulasi yang tepat yaitu kegiatan menganyam kertas dan melipat kertas (origami).

\section{Kesimpulan}

Berdasarkan hasil penelitian tersebut di atas, maka dapat disimpulkan bahwa:

1. Metode pemberian tugas menganyam kertas dapat meningkatkan kemampuan motorik halus anak Kelompok B TK Al-Mujahidin Tomohon. Kesimpulan tersebut terbukti dengan adanya peningkatan kemampuan motorik halus pada siklus I yaitu aspek menganyam kertas terdapat 3 orang anak (18,75\%) yang masuk kategori berkembang sangat baik, pada siklus II kemampuan anak menunjukkan peningkatan dalam kegiatan menganyam kertas menjadi 11 orang anak (68,75\%).

2. Metode pemberian tugas melipat kertas (origami) dapat meningkatkan kemampuan motorik halus anak di kelompok B TK Al-Mujahidin Tomohon. Pada siklus I terdapat 5 orang anak (31,25\%) yang masuk kategori berkembang sangat baik dan pada siklus II menunjukkan peningkatan dalam kegiatan melipat kertas (origami) menjadi 12 orang anak (75.00\%). 


\section{Saran}

Berdasarkan hasil penelitian disarankan, pertama kepada guru agar menerapkan metode pemberian tugas menganyam kertas dan melipat kertas (origami) pada proses belajar mengajar karena metode ini dapat mendorong anak terbiasa dalam melakukan kegiatan apa saja, menumbuhkan motivasi, dan minat anak untuk belajar sehingga dapat meningkatkan kemampuan motorik halus anak. Kedua, kepada kepala sekolah (pimpinan) agar memberi kesempatan kepada guru untuk melakukan perbaikan pembelajaran dalam upaya meningkatkan kemampuannya sebagai guru profesional. Dan, ketiga, kepada lembaga (TK/RA) agar dapat mempertimbangkan penyusunan bahan pembelajaran yang berorientasi pada pemberian tugas khususnya menganyam dan melipat kertas (origami).

\section{Referensi}

Departemen Pendidikan Nasional. (2003). Undang-Undang RI Nomor Nomor 20 Tahun 2003. Jakarta: Depdiknas.

Djamarah, S. B., \& Zain, A. (2010). Strategi Belajar Mengajar. Jakarta: Rineke Cipta.

Montolalu, B. E. F. (2005). Bermaian dan Permainan Anak. Jakarta: Universitas Terbuka.

Pamadhi, H., \& Sukardi, E. (2008). Seni Keterampilan Anak. Jakarta: Universitas Terbuka.

Purnamasari, N. K. N., Negara, I. G. A. O., \& Suara, I. M. (2014). Penerapan Metode Demonstrasi melalui Kegiatan Melipat Kertas (Origami) untuk Meningkatkan Perkembangan Motorik Halus Anak. E-Journal PG-PAUD Universitas Pendidikan Ganesha, 2(1).

Setiani, S. (2007). Bermain dan Permainan Anak. (B. E. F. Montolalu, Ed.). Jakarta: Universitas Terbuka.

Sumanto. (2006). Pengembangan Kreativitas Seni Rupa Anak SD. Jakarta:

Departemen Pendidikan Nasional Direktorat Jenderal Pendidikan Tinggi, Direktorat Pendidikan Tenaga Kependidikan dan Ketenagaan Perguruan Tinggi. 